\title{
Economics of Winter Vegetables Marketing in Bishnupur District of Manipur, India
}

\author{
A. Elavarasan", Y. Chakrabarty Singh, Kh. Rishikanta Singh and N. Okendro Singh \\ College of Agriculture, Central Agricultural University, Imphal-795004, Manipur(India) \\ *Corresponding author
}

Ke y w o r d s
Marketing
efficiency,
Middlemen, Price
spread, Marketing
cost and Marketing
margin

\section{Introduction}

The growing importance of vegetables in Indian economy can be well appreciated in terms of their rising domestic demand on account of increase in population and per capita income; their increasing export potential and increased vegetables consumption urban and rural area; need for providing employment opportunities in the rural area, and vegetables being relatively more remunerative crops. It can be grown within a short time period and more than one crop can be grown within a crop season. There are a large number of vegetables having different varieties, which can be grown throughout the year. However, the largest numbers of vegetables are grown according to climatic condition and irrigation facilities. In north eastern state of Manipur growing of temperate vegetables like broad bean, cabbage, cauliflower and pea are prominent during the period of time and marketing of these vegetables from valley areas to other regions of the state in an efficient manner with different marketing functionaries. Manipur is situated in the north eastern region of the country of the total geographical area, about nine-tenths constitute the hills, which surround the remaining one-tenth of the 
valley area. Agriculture is the mainstay of the state's economy. It engages about 76 per cent of the total workforce of the state. The size of the cultivated area is, however only 9.41 per cent of the total geographical area of the state. Of this cultivated area, 52 per cent is confined to the valley area. About 67 per cent of the total population of the valley region is engaged in agriculture. With the technological development in the agricultural field, India has made rapid stride in horticulture too along with increased food grain production.

\section{Materials and Methods}

The study was conducted in Bishnupur district of Manipur using Multi-stage sampling method was followed (Ashok, M.V. and Himanshu Pandey) for the selection of following steps. Out of the three blocks, two blocks selected purposively in that each block five villages selected purposively, in that each village 10 farmers selected randomly and totally 100 sample farmers selected. The data was collected through personal interview method through a structured developed pretested schedule. The collected data were analyzed using appropriate marketing formula, statistical tools and analysis.

\section{Results and Discussion}

Channel-wise marketing cost and marketing margin of broad bean is shown in table 1 . Marketing cost and marketing margin vary considerably from channel to channel and were related directly to the length of the channel, i.e., longer the channel, more were the marketing cost and marketing margin. Channel 1 (Producer - Village trader Wholesaler - Retailer - Consumer) being the longest channel and in this channel the highest marketing cost and marketing margin per quintal, i.e., Rs. 423.28 and Rs. 2231.49 respectively were observed. Channel 111 (Producer - Consumer) is the shortest channel accounting for lowest marketing cost, i.e., Rs.88.27 per quintal. Channel 2 (Producer Retailer - Consumer) is the next shortest channel accounting for lower marketing cost and marketing margin, i.e., Rs. 304.11 and Rs. 897.05 per quintal respectively. Thus it can be concluded that as the length of channel increases the marketing cost and marketing margin also increases and vice-versa.

The price spread of broad bean marketed in imphal market through different channels of trade is presented in table 2 . The perusal of the table indicates that the producers share in consumer rupees was highest in channel 111 (98.96\%) followed by channel 11 and channel $1(86.65 \%$ \& $72.05 \%)$ respectively. The producers, who sold their produce through channel 1, channel 11 and channel 111 received Rs. 68.45, Rs. 77.98 and Rs. 84.12 per kg respectively. The total marketing cost paid by the producer formed 4.24, 3.05, and 0.88 percent of consumer's rupee in case of channel 1, channel 11, and channel 111 respectively. Marketing margin incurred per $\mathrm{kg}$ by the producers was highest in channel 1 $(23.5 \%)$ than channel $11(9.98 \%)$. Therefore it is clear from the table 3 that channel 111 can be considered to be the most efficient among the different channel for sale of broad bean.

The result indicates that in all the selected markets, there were information linkages about the broad bean prices and its arrival in other markets.

The findings of multiple linear regression model is presented in table 4. that shows negative and significant relationship between marketing efficiency and marketing cost and marketing margin. The volume of produce had positive and significant relationship which shows that large broad bean farmers fetched better prices in the market. Though increasing numbers of market intermediaries had negative relationship with marketing 
efficiency yet this factor was not significant on the marketing efficiency of broad bean.

Channel-wise marketing cost and marketing margin of cabbage is shown in Table 5. Marketing cost and marketing margin vary considerably from channel to channel and were related directly to the length of the channel, i.e., longer the channel, more were the marketing cost and marketing margin. Channel 1 (Producer - Village trader Wholesaler - Retailer - Consumer) being the longest channel and in this channel the highest marketing cost and marketing margin per quintal, i.e., Rs. 361.1 and Rs. 791.83 respectively were observed. Channel 111 (Producer - Consumer) is the shortest channel accounting for lowest marketing cost, i.e., Rs.48.47 per quintal. Channel 2 (Producer Retailer - Consumer) is the next shortest channel accounting for lower marketing cost and marketing margin, i.e., Rs. 186.71 and Rs. 462.19 per quintal respectively. Thus it can be concluded that as the length of channel increases the marketing cost and marketing margin also increases and vice-versa.

The producers who sold their produce through channel 1, channel 11 and channel 111 received Rs. 18.47, Rs. 13.51 and Rs. 17.49 per $\mathrm{kg}$ respectively. The total marketing cost paid by the producer formed 3.62, 1.87, and 0.6 percent of consumer's rupee in case of channel 1, channel 11, and channel 111 respectively. Marketing margin incurred per $\mathrm{kg}$ by the producers was highest in channel 1 $(26.39 \%)$ than channel ll $(23.11 \%)$. Therefore it is clear from the table 6 and 7 that channel 111 can be considered to be the most efficient among the different channel for sale of cabbage.

The result indicates that in all the selected markets, there were information linkages about the cabbage prices and its arrival in other markets.
The findings of multiple linear regression model is presented in table 8. that shows negative and significant relationship between marketing efficiency and marketing cost and marketing margin. The volume of produce had positive and significant relationship which shows that large cabbage farmers fetched better prices in the market. Though increasing numbers of market intermediaries had negative relationship with marketing efficiency yet this factor was not significant on the marketing efficiency of cabbage.

Channel 1 (Producer - Village trader Wholesaler - Retailer - Consumer) being the longest channel and in this channel the highest marketing cost and marketing margin per quintal, i.e., Rs. 325.91 and Rs. 1814.78 respectively were observed. Channel 111 (Producer - Consumer) is the shortest channel accounting for lowest marketing cost, i.e., Rs.46.54 per quintal. Channel 2 (Producer Retailer - Consumer) is the next shortest channel accounting for lower marketing cost and marketing margin, i.e., Rs. 231.75 and Rs. 938.56 per quintal respectively. Thus it can be concluded that as the length of channel increases the marketing cost and marketing margin also increases and vice-versa (Table 9).

The producers, who sold their produce through channel 1, channel 11 and channel 111 received Rs. 33.59, Rs. 28.3 and Rs. 37.5 per $\mathrm{kg}$ respectively. The total marketing cost paid by the producer formed 5.93, 5.79, and 0.5 percent of consumer's rupee in case of channel 1, channel 11, and channel 111 respectively. Marketing margin incurred per $\mathrm{kg}$ by the producers was highest in channel 1 $(32.99 \%)$ than channel $11(24.5 \%)$. Therefore it is clear from the table 10 and 11 that channel 111 can be considered to be the most efficient among the different channel for sale of cauliflower. 
The result indicates that in all the selected markets, there were information linkages about the cauliflower prices and its arrival in other markets.

The findings of multiple linear regression model is presented in table 12 and shows negative and significant relationship between marketing efficiency and marketing cost and marketing margin. The volume of produce had positive and significant relationship which shows that large cauliflower farmers fetched better prices in the market. Though increasing numbers of market intermediaries had negative relationship with marketing efficiency yet this factor was not significant on the marketing efficiency of cauliflower.

Table.1 Marketing cost and marketing margin of broad bean (Rs/q)

\begin{tabular}{|l|c|c|c|}
\hline \multirow{2}{*}{ Item } & Channel 1 & Channel 2 & Channel 3 \\
\cline { 2 - 4 } Farm gate price & Cost & Cost & Cost \\
\hline Marketing Cost & 6845.26 & 7798.83 & 8411.73 \\
\hline Producer & & & 88.27 \\
\hline Trader & $(34.77$ & 201.16 & $(100)$ \\
\hline Wholesaler & 85.41 & $(66.15)$ & - \\
\hline Retailer & $(20.18)$ & - & - \\
\hline Total Marketing Cost & 74.72 & - & - \\
\hline Marketing Margin & $(17.65)$ & & 88.27 \\
\hline Trader & 108.38 & 102.95 & - \\
\hline Wholesaler & $(25.60)$ & $(33.85)$ & - \\
\hline Retailer & 423.28 & 304.11 & - \\
\hline Total Marketing Margin & 914.59 & & - \\
\hline Consumer Price & $(40.98)$ & - & 8500 \\
\hline
\end{tabular}

Table.2 Price spread of broad bean through different marketing channel (Rs/kg)

\begin{tabular}{|c|c|c|c|c|c|c|c|}
\hline \multirow[b]{2}{*}{ S. No } & \multirow[b]{2}{*}{ Particulars } & \multicolumn{2}{|c|}{ Channel I } & \multicolumn{2}{|c|}{ Channel II } & \multicolumn{2}{|c|}{ Channel III } \\
\hline & & Rs. & $\%$ & Rs. & $\%$ & Rs. & $\%$ \\
\hline 1. & Net price received by the farmers & 68.45 & 72.05 & 77.98 & 86.65 & 84.12 & 98.96 \\
\hline 2. & Marketing cost & 4.24 & 4.45 & 3.05 & 3.37 & 0.88 & 1.04 \\
\hline 3. & Marketing margin & 22.31 & 23.5 & 8.97 & 9.98 & 0 & 0 \\
\hline 4. & Price paid by the consumer & 95 & 100 & 90 & 100 & 85 & 100 \\
\hline
\end{tabular}


Table.3 Correlation matrixes for broad bean prices in different selected markets

\begin{tabular}{|l|l|l|l|}
\hline Markets & Bishnupur & Nambol & Imphal \\
\hline Bishnupur & 1 & & \\
\hline Nambol & $0.941^{* *}$ & 1 & \\
\hline Imphal & $0.980^{* *}$ & $0.962 * *$ & 1 \\
\hline
\end{tabular}

** Correlation is significant at the 0.01 level (2- tailed)

Table.4 Factors affecting marketing efficiency of broad bean

\begin{tabular}{|l|l|c|c|}
\hline S. No. & Factors & Coefficient & 't' value \\
\hline 1. & Constant & 3.913 & 0.360 \\
\hline 2. & Marketing cost $\left(\mathrm{X}_{1}\right)$ & $-0.106^{* * *}$ & -2.524 \\
\hline 3. & Marketing margin $\left(\mathrm{X}_{2}\right)$ & $-0.029^{*}$ & -1.589 \\
\hline 4. & Volume of the produce handled $\left(\mathrm{x}_{\mathbb{1}}\right)$ & $0.434^{* * *}$ & 4.956 \\
\hline 5. & $\begin{array}{l}\text { Length of the market channel } \\
\text { (No. of market intermediaries) }\left(\mathrm{x}_{4}\right)\end{array}$ & -3.110 & -1.070 \\
\hline 6. & $\mathrm{R}^{2}$ & \multicolumn{2}{|c|}{0.544} \\
\hline 7. & Adjusted $\mathrm{R}^{2}$ & \multicolumn{2}{|c|}{0.517} \\
\hline 8. & No. of observation $(\mathrm{n})$ & \multicolumn{2}{|c|}{100} \\
\hline
\end{tabular}

Note: ***,* indicate significance at 1 percent, 10percent level respectively

Table.5 Marketing cost and marketing margin of cabbage (Rs/q)

\begin{tabular}{|l|c|c|c|}
\hline & Channel 1 & Channel 2 & Channel 3 \\
\hline Item & Cost & Cost & Cost \\
\hline Farm gate price & 1847.07 & 1351.1 & 1749.14 \\
\hline Marketing Cost & & & 148.89 \\
\hline Producer & 152.93 & $(79.75)$ & (100) \\
\hline Trader & $(42.35)$ & - & - \\
\hline Wholesaler & 82.22 & - & - \\
\hline Retailer & $(22.77)$ & & - \\
\hline Total Marketing Cost & 54.64 & 37.81 & 48.15 \\
\hline Marketing Margin & $(15.13)$ & $(20.25)$ & $(100)$ \\
\hline Trader & 71.31 & 186.71 & - \\
\hline Wholesaler & $(19.75)$ & $(100)$ & - \\
\hline Retailer & 361.10 & - & - \\
\hline Total Marketing Margin & $(100)$ & & \\
\hline Consumer Price & 117.78 & - & - \\
\hline
\end{tabular}


Table.6 Price spread of cabbage through different marketing channel (Rs/kg)

\begin{tabular}{|c|c|c|c|c|c|c|c|}
\hline \multirow[t]{2}{*}{ S. No. } & \multirow[t]{2}{*}{ Particulars } & \multicolumn{2}{|c|}{ Channel I } & \multicolumn{2}{|c|}{ Channel Il } & \multicolumn{2}{|c|}{ Channel Ill } \\
\hline & & Rs. & $\%$ & Rs. & $\%$ & Rs. & $\%$ \\
\hline 1. & Net price received by the farmers & 18.47 & 61.56 & 13.51 & 67.55 & 17.49 & 96.8 \\
\hline 2. & Marketing cost & 3.62 & 12.03 & 1.87 & 9.33 & 0.6 & 3.2 \\
\hline 3. & Marketing margin & 7.91 & 26.39 & 4.62 & 23.11 & - & - \\
\hline 4. & Price paid by the consumer & 30 & 100 & 20 & 100 & 18 & 100 \\
\hline
\end{tabular}

Table.7 Correlation matrixes of cabbage in different selected markets

\begin{tabular}{|l|l|l|l|}
\hline Markets & Bishnupur & Nambol & Imphal \\
\hline Bishnupur & 1 & & \\
\hline Nambol & $0.815 * *$ & 1 & \\
\hline Imphal & $0.975 * *$ & $0.867 * *$ & 1 \\
\hline
\end{tabular}

** Correlation is significant at the 0.01 level (2- tailed)

Table.8 Factors affecting marketing efficiency of cabbage

\begin{tabular}{|l|l|c|c|}
\hline S. No. & Factors & Coefficient & 't' value \\
\hline 1. & Constant & 4.534 & 1.092 \\
\hline 2. & Marketing cost $\left(\mathrm{x}_{1}\right)$ & $-0.278 * *$ & -3.26 \\
\hline 3. & Marketing margin $\left(\mathrm{x}_{2}\right)$ & $-0.012 * *$ & -1.966 \\
\hline 4. & Volume of the produce handled $\left(\mathrm{x}_{\mathrm{g}}\right)$ & $0.103 * * *$ & 2.323 \\
\hline 5. & Length of the market channel & -0.0305 & -1.021 \\
\hline 6. & (No. of market intermediaries) $\left(\mathrm{x}_{4}\right)$ & 0.563 & \\
\hline 7. & $\mathrm{R}^{2}$ & 0.532 \\
\hline 8. & Adjusted $\mathrm{R}^{2}$ & \multicolumn{2}{|c|}{100} \\
\hline
\end{tabular}

Note: $* * *, * *$ indicate significance at 1 percent, 5 percent level respectively 
Table.9 Marketing cost and marketing margin of cauliflower (Rs/q)

\begin{tabular}{|l|c|c|c|}
\hline \multirow{2}{*}{ Item } & Channel 1 & Channel 2 & Channel 3 \\
\cline { 2 - 4 } Farm gate price & Cost & Cost & Cost \\
\hline Marketing Cost & 3359.3 & 2829.67 & 3753.45 \\
\hline Producer & & & 46.54 \\
& 140.69 & 170.31 & $(100)$ \\
\hline Trader & $(43.17)$ & $(73.49)$ & - \\
\hline Wholesaler & 82.79 & - & - \\
& $(25.40)$ & & - \\
\hline Retailer & 43.34 & - & 46.54 \\
\hline Total Marketing Cost & $(13.29)$ & 61.44 & - \\
\hline Marketing Margin & 59.07 & $(26.51)$ & - \\
\hline Trader & $(18.12)$ & 231.75 & - \\
\hline Wholesaler & 325.91 & - & - \\
\hline Retailer & 417.20 & & - \\
\hline Total Marketing Margin & $(22.99)$ & - & 3800 \\
\hline Consumer Price & 456.65 & 938.56 & \\
\hline
\end{tabular}

Table.10 Price spread of cauliflower through different market channel (Rs/kg)

\begin{tabular}{|l|l|l|l|l|l|l|l|}
\hline S. No. & Particulars & \multicolumn{2}{|c|}{ Channel I } & \multicolumn{2}{l|}{ Channel II } & \multicolumn{2}{l|}{ Channel III } \\
\cline { 3 - 8 } & & Rs. & \% & Rs. & \% & Rs. & $\%$ \\
\hline 1. & Net price received by the farmers & 33.59 & 61.08 & 28.3 & 70.74 & 37.5 & 98.4 \\
\hline 2. & Marketing cost & 3.26 & 5.93 & 2.32 & 5.79 & 0.5 & 1.6 \\
\hline 3. & Marketing margin & 18.15 & 32.99 & 9.38 & 24.5 & - & - \\
\hline 4. & Price paid by the consumer & 55 & 100 & 40 & 100 & 38 & 100 \\
\hline
\end{tabular}

Table.11 Correlation matric of cauliflower in different selected markets

\begin{tabular}{|l|l|l|l|}
\hline Markets & Bishnupur & Nambol & Imphal \\
\hline Bishnupur & 1 & & \\
\hline Nambol & $0.741^{* *}$ & 1 & \\
\hline Imphal & $0.822^{* *}$ & $0.806 * *$ & 1 \\
\hline
\end{tabular}

** Correlation is significant at the 0.01 level (2- tailed) 
Table.12 Factors affecting marketing efficiency of cauliflower

\begin{tabular}{|l|l|c|c|}
\hline S. No. & Factors & Coefficient & ' $\mathbf{t}$ ' value \\
\hline 1. & Constant & 3.478 & 1.305 \\
\hline 2. & Marketing cost $\left(\mathrm{x}_{1}\right)$ & $-0.187 * * *$ & -3.774 \\
\hline 3. & Marketing margin $\left(\mathrm{x}_{2}\right)$ & $-0.011^{*}$ & -1.637 \\
\hline 4. & Volume of the produce handled $\left(\mathrm{x}_{\mathrm{g}}\right)$ & $0.243 * * *$ & 6.084 \\
\hline 5. & Length of the market channel & -1.362 & -0.178 \\
\hline 6. & (No. of market intermediaries) $\left(\mathrm{x}_{4}\right)$ & 0.688 \\
\hline 7. & $\mathrm{R}^{2}$ & 0.558 \\
\hline 8. & Adjusted $\mathrm{R}^{2}$ & \multicolumn{2}{|c|}{100} \\
\hline
\end{tabular}

Note: $* * *, *$ indicate significance at 1 percent, 10 percent level respectively

Table.13 Marketing cost and Marketing margin of pea (Rs/q)

\begin{tabular}{|c|c|c|c|}
\hline & Channel 1 & Channel 2 & Channel 3 \\
\hline Item & Cost & Cost & Cost \\
\hline Farm gate price & 8836.48 & 7805.02 & 9404.47 \\
\hline \multicolumn{4}{|l|}{ Marketing Cost } \\
\hline Producer & $\begin{array}{l}163.52 \\
(41.32)\end{array}$ & $\begin{array}{l}194.99 \\
(63.26)\end{array}$ & $\begin{array}{l}95.53 \\
(100)\end{array}$ \\
\hline Trader & $\begin{array}{c}87.70 \\
(22.16)\end{array}$ & - & - \\
\hline Wholesaler & $\begin{array}{c}83.07 \\
(20.99)\end{array}$ & - & - \\
\hline Retailer & $\begin{array}{c}61.39 \\
(15.51)\end{array}$ & $\begin{array}{l}113.23 \\
(36.74)\end{array}$ & - \\
\hline $\begin{array}{l}\text { Total Marketing } \\
\text { Cost }\end{array}$ & 395.69 & 308.21 & 95.53 \\
\hline \multicolumn{4}{|l|}{$\begin{array}{l}\text { Marketing } \\
\text { Margin }\end{array}$} \\
\hline Trader & $\begin{array}{c}912.3 \\
(32.96)\end{array}$ & - & - \\
\hline Wholesaler & $\begin{array}{l}916.93 \\
(33.13)\end{array}$ & - & - \\
\hline Retailer & $\begin{array}{l}938.33 \\
(33.90)\end{array}$ & $\begin{array}{c}1886.76 \\
(100)\end{array}$ & - \\
\hline $\begin{array}{l}\text { Total Marketing } \\
\text { Margin }\end{array}$ & 2767.83 & 1886.76 & - \\
\hline Consumer Price & 12000 & 10000 & 9500 \\
\hline
\end{tabular}


Table.14 Price spread of pea through different marketing channel (Rs/kg)

\begin{tabular}{|l|l|l|l|l|l|l|l|}
\hline S. No. & Particulars & Channel I & \multicolumn{2}{|c|}{ Channel II } & \multicolumn{2}{l|}{ Channel III } \\
\hline & & Rs. & \% & Rs. & \% & Rs. & \% \\
\hline 1. & Net price received by the farmers & 88.36 & 73.64 & 78.05 & 78.05 & 94.04 & 98.2 \\
\hline 2. & Marketing cost & 3.96 & 3.29 & 3.08 & 3.08 & 0.96 & 1.2 \\
\hline 3. & Marketing margin & 27.68 & 23.06 & 18.87 & 18.87 & - & - \\
\hline 4. & Price paid by the consumer & 120 & 100 & 100 & 100 & 95 & 100 \\
\hline
\end{tabular}

Table.15 Correlation matric of pea in different selected markets

\begin{tabular}{|l|l|l|l|}
\hline Markets & Bishnupur & Nambol & Imphal \\
\hline Bishnupur & 1 & & \\
\hline Nambol & $0.927^{* *}$ & 1 & \\
\hline Imphal & $0.962^{* *}$ & $0.835^{* *}$ & 1 \\
\hline
\end{tabular}

Table.16 Factors affecting marketing efficiency of pea

\begin{tabular}{|l|l|l|l|}
\hline S. No. & Factors & Coefficient & ' $\mathbf{t}$ ' value \\
\hline 1. & Constant & 6.094 & 0.737 \\
\hline 2. & Marketing cost $(\mathrm{x} 1)$ & $-0.868^{* * *}$ & -6.453 \\
\hline 3. & Marketing margin $(\mathrm{x} 2)$ & $-1.143^{* * *}$ & -4.447 \\
\hline 4. & Volume of the produce handled (x3) & $1.552^{* * *}$ & 6.642 \\
\hline 5. & $\begin{array}{l}\text { Length of the market channel } \\
\text { (No. of market intermediaries) }(\mathrm{X} 4)\end{array}$ & -6.164 & -1.050 \\
\hline 6. & $\mathrm{R}^{2}$ & 0.510 & \\
\hline 7. & Adjusted $\mathrm{R}^{2}$ & 0.490 & \\
\hline 8. & No. of observation $(\mathrm{n})$ & 100 & \\
\hline Note: $* * *$ indicate significance at 1 percent level respectively & \\
\hline
\end{tabular}

Marketing cost and marketing margin vary considerably from channel to channel and were related directly to the length of the channel, i.e., longer the channel, more were the marketing cost and marketing margin. Channel 1 (Producer - Village trader Wholesaler - Retailer - Consumer) being the longest channel and in this channel the highest marketing cost and marketing margin per quintal, i.e., Rs. 395.68 and Rs. 2767.56 respectively were observed. Channel 111 (Producer - Consumer) is the shortest channel accounting for lowest marketing cost, i.e., Rs.95.53 per quintal. Channel 2 (Producer Retailer - Consumer) is the next shortest channel accounting for lower marketing cost and marketing margin, i.e., Rs. 194.98 and Rs. 1886.76 per quintal respectively. Thus it can be concluded that as the length of channel increases the marketing cost and marketing margin also increases and vice-versa (Table 13).

It is clear from the table 14 that channel 111 can be considered to be the most efficient among the different channel for sale of pea.

The result indicates that in all the selected markets, there were information linkages about the pea prices and its arrival in other markets (Table 15). 
The findings of multiple linear regression model is presented in table 16. that shows negative and significant relationship between marketing efficiency and marketing cost and marketing margin. The volume of produce had positive and significant relationship which shows that large pea farmers fetched better prices in the market. Though increasing numbers of market intermediaries had negative relationship with marketing efficiency yet this factor was not significant on the marketing efficiency of pea.

\section{Acknowledgement}

The authors acknowledge the contributions of A. Elavarasan, Y. Chakrabarty Singh, Kh. Rishikanta Singh and N. Okendro Singh, College of Agriculture, Central Agricultural University, Imphal, Manipur (India) for their technical support and valuable contributions to the manuscript.

\section{References}

Akter, S. and Islam, M.S. (2011). An economic analysis of winter vegetable production in some selected area of Narsingdi district. Journal of
Bangladesh Agricultural University, 9 (2): 241-246.

Ashok, M.V. and Himanshu Pandey. (2017). Agricultural marketing- How farmers face the challenge. Indian Journal of Agricultural Marketing, Pp. 48-60.

Baba, S. H., Wani, M. H. and Yousuf, S. (2010). Marketed Surplus and Price Spread of Vegetables in Kashmir Valley. Agricultural Economics Research Review Vol. (23): 115-127.

Gupta, S. P. and Rathore, N. S. (1999). Disposal pattern and constraints in vegetable marketing: A case study of Raipur District of Madhya Pradesh. Agricultural Marketing, 43: 53-59.

Hossain, M. D., Siddique, M. A., Islam, M. S., Salam, M. A., and Hossain, M. A. (2002). Profitability in cauliflower production and its domestic marketing system in Bangladesh. Economic Affairs (Calcutta); 47(4):244-252..

Imtiyaz, H. and Soni, P. (2013). Evaluation of marketing supply chain performance of fresh vegetables in Allahabad. International Journal of Management Sciences and Business Research, 3(1): 72-83.

\section{How to cite this article:}

Elavarasan, A., Y. Chakrabarty Singh, Kh. Rishikanta Singh and Okendro Singh, N. 2019. Economics of Winter Vegetables Marketing in Bishnupur District of Manipur. Int.J.Curr.Microbiol.App.Sci. 8(06): 1193-1202. doi: https://doi.org/10.20546/ijcmas.2019.806.147 